\title{
Correction to: Assessment of biomarkers of early kidney damage and exposure to pollutants in artisanal mercury mining workers from Mexico
}

\author{
Lorena Díaz de León-Martínez ${ }^{1}$ - Manolo Ortega-Romero ${ }^{2}$ Arturo Gavilán-García ${ }^{3}$. Olivier C. Barbier² . \\ Leticia Carrizalez-Yáñez ${ }^{1} \cdot$ Evelyn Van-Brusel $^{1} \cdot$ Fernando Díaz-Barriga $^{1} \cdot$ Rogelio Flores-Ramírez $^{4} \mathbb{0}$
}

Published online: 30 October 2021

(c) Springer-Verlag GmbH Germany, part of Springer Nature 2021

\section{Correction to: Environmental Science and Pollution Research (2021) 28:14115-14120}

https://doi.org/10.1007/s11356-021-16,628-x

Firstly, adscription number 3, which belongs to Dr. Arturo Gavilán García, is modified in this paper.

Firstly, in the abstract I kindly request the correction of the units of the concentrations presented:

Artisanal mercury mining (AMM) is an informal economic activity that employs low technology and limited protection, and poses a risk to workers and their families; due to the extraction process, these scenarios involve exposure to complex mixtures of pollutants that synergistically aggravate the health of miners and people living near the site. Although mercury is the predominant pollutant, there are others such as polycyclic aromatic hydrocarbons (PAHs), toluene, arsenic, and lead which have been classified as nephrotoxic pollutants. Therefore, the purpose of this research was to evaluate the association between exposure to a complex mixture

The original article can be found online at https://doi.org/10.1007/ s11356-021-16628-x.

Rogelio Flores-Ramírez

rfloresra@ conacyt.mx

1 Centro de Investigación Aplicada en Ambiente y Salud (CIAAS), Avenida Sierra Leona No. 550Colonia Lomas Segunda Sección, CP 78210 San Luis Potosí, SLP, Mexico

2 Departamento de Toxicología, Centro de Investigación y de Estudios Avanzados del Instituto Politécnico Nacional (CINVESTAV-IPN), Ciudad de Mexico, Mexico, Mexico

3 National Institute of Ecology and Climate Change, SEMARNAT. Blvd. Adolfo Ruíz Cortines, 4209 Jardines en La Montaña Ciudad de Mexico, Mexico

4 CONACYT Research Fellow, Coordinación para la Innovación y Aplicación de la Ciencia y la Tecnología (CIACYT), Avenida Sierra Leona No. 550Colonia Lomas Segunda Sección, CP 78210 San Luis Potosí, SLP, Mexico of pollutants (mercury, lead, arsenic, PAHs, and toluene) and kidney damage in artisanal $\mathrm{Hg}$ mining workers through early kidney damage proteins (KIM-1, OPN, RBP-4, NGAL, and Cys-C). The results demonstrate the presence of OH-PAHs at concentrations of $9.21(6.57-80.63) \mu \mathrm{g} / \mathrm{L}$, hippuric acid as a biomarker of exposure to toluene, $\mathrm{As}$ and $\mathrm{Pb} 655.1$ (203.8-1231) $\mathrm{mg} / \mathrm{L}, 24.05$ (1.24-42.98) $\mu \mathrm{g} / \mathrm{g}$ creatinine, and $4.74(2.71-8.14) \mu \mathrm{g} / \mathrm{dL}$, respectively, and urinary $\mathrm{Hg} 503.4$ (177.9-878.7) $\mu \mathrm{g} / \mathrm{g}$ creatinine in the study population. As well as biomarkers of kidney damage, NGAL and RPB-4 were found in $100 \%$ of the samples, KIM- 1 and Cys-C in $44.1 \%$, and OPN in $41 \%$ of the miners. Significant correlations were found between several of the evaluated pollutants and early kidney damage proteins. Our results demonstrate the application of the early kidney damage biomarkers for the assessment of damage caused by the exposure to mixtures of pollutants and, therefore, the urgent need for monitoring in AMM areas.

And secondly, I kindly request that the following statement be presented in the acknowledgments section:

The authors acknowledge grants and fellowships from National Council on Science and Technology- Sectoral Research FOSEC SS/IMSS/ISSSTE \# A3-S-38681. And the authors acknowledge the entire sampling team of the Total Health Laboratory of the Universidad Autónoma de San Luis Potosí, and Kelvin Saldaña Villanueva for his contribution to the development of this work.

Publisher's Note Springer Nature remains neutral with regard to jurisdictional claims in published maps and institutional affiliations. 